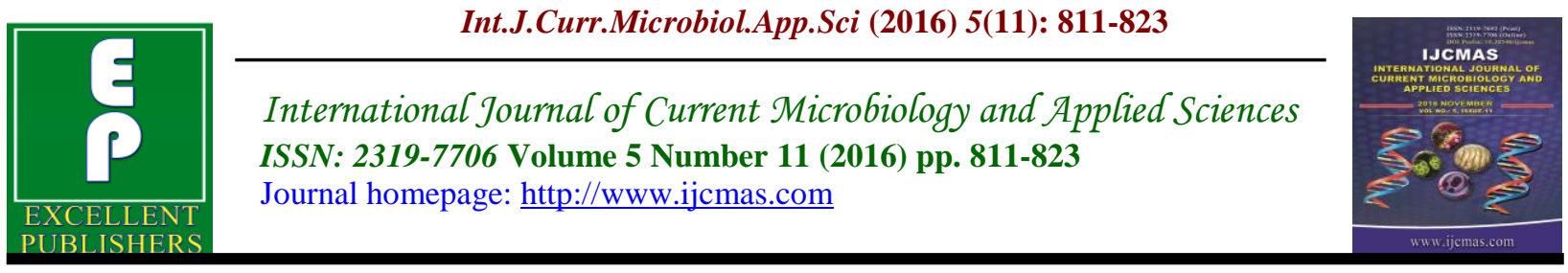

Original Research Article

http://dx.doi.org/10.20546/ijcmas.2016.511.092

\title{
The Effect of Nitrogen and Potassium Fertilizers on Yield and Quality of Sweet Sorghum Varieties under Arid Regions Conditions
}

\author{
A.A.A. Mekdad and A.M.A. El-Sherif* \\ Agronomy Department, Faculty of Agriculture, Fayoum University, 63514 - Fayoum, Egypt \\ *Corresponding author
}

Keywords

Sweet sorghum, varieties, nitrogen, potassium and stepwise regression.

\section{Article Info}

Accepted:

23 October 2016

Available Online:

10 November 2016

\section{A B S T R A C T}

Two field experiments conducted during 2013 and 2014 seasons at the farm of the Faculty of Agriculture, Demo, Fayoum University, Egypt, to evaluate two sweet sorghum varieties under the effect of three nitrogen levels and three potassium levels on yield and its attributes. The experiment was set up according to threefactorial (Split-split plot) block design in three replications, the main plots were assigned to sweet sorghum varieties viz., Honey $\left(\mathrm{V}_{1}\right)$ and Brandes $\left(\mathrm{V}_{2}\right)$. The sub plots were occupied with three levels of nitrogen at the level of $80\left(\mathrm{~N}_{1}\right), 100\left(\mathrm{~N}_{2}\right)$ and $120\left(\mathrm{~N}_{3}\right) \mathrm{Kg} \mathrm{N} / \mathrm{fed}\left(\mathrm{fed}=4200 \mathrm{~m}^{2}=0.405\right.$ hectare) in three equal doses. Potassium sulphate $\left(48 \% \mathrm{~K}_{2} \mathrm{O}\right)$ applied to the soil at the level of $25\left(\mathrm{~K}_{1}\right), 50\left(\mathrm{~K}_{2}\right)$ and $75\left(\mathrm{~K}_{3}\right) \mathrm{kg} \mathrm{K}_{2} \mathrm{SO}_{4} \backslash \mathrm{fed}$ were arranged in the sub-sub plots treatments and applied in three equal doses. Results indicated that the effect of nitrogen levels as well as, potassium levels had a highly significant positive effect on yield, yield components and quality traits, varieties differed significantly in stem diameter, seed index and theoretical ethanol yield in both seasons, the highest former traits produced by Brandes variety $\left(\mathrm{V}_{2}\right)$. The highest values of seed index in both seasons, as well as brix, juice extraction, juice yield and sugar yield in the first season, while stem length, leaf weight and leaves yield in the second season were obtained by Brandes $\left(\mathrm{V}_{2}\right)$ variety with $120 \mathrm{~kg}$ N/fed $\left(\mathrm{N}_{3}\right)$ with $75\left(\mathrm{~K}_{3}\right) \mathrm{kg}$ Klfed. The highest yields of sugar and juice were 1.83 and $10.68 \mathrm{t} / \mathrm{fed}$ were obtained from the trilateral interaction among Brandes $\left(\mathrm{V}_{2}\right)$ variety with $120 \mathrm{~kg} \mathrm{~N} / \mathrm{fed}\left(\mathrm{N}_{3}\right)$ with $75\left(\mathrm{~K}_{3}\right) \mathrm{kg} \mathrm{K} / \mathrm{fed}$ in the first season, respectively. According to, best-subsets regression the pest model for the stem height, stem diameter, stem weight, stem yield, brix $\%$, sucrose $\%$, purity $\%$ and juice extraction $\%$ showed that high adjusted $\mathrm{R}^{2}=99.80$ and $99.90 \%$, in the $1^{\text {st }}$ and $2^{\text {nd }}$ seasons, respectively.

\section{Introduction}

Sweet sorghum (Sorghum biocolor (L.) Moench) consider as a $\mathrm{C}_{4}$ plant and Characterized by high stalk and sugar yield (Antonopoulou et al., 2008). The high sucrose rate of its stalk is not as much as sugarcane and sugar beet plants, however it has a lower water requirement (40 - 50\% less water than maize and four times less water than sugarcane), and drought tolerant, meanwhile, its speedy growth rate early ripeness high total energy value addition to, suitable to sub-tropical and temperate region 
of the world (Martin et al., 1990; Howell et al., 1997 and Rego et al., 2003).

In arid and semi-arid environments including Egypt, limited rainfall and low soil fertility have reduced crop productivity, particularly sugar cane crop that produces about $63 \%$ of sugar production worldwide, requiring high water availability (20000$24000 \mathrm{~m}^{3}$ irrigation water/ha) and high soil fertility (Singh et al., 2008). Appropriate soil, water administration, and choice of convenient varieties seriously influence crop productivity and soil sustainability the highly values (Benlhabib et al., 2014).

Productivity of sweet sorghum is influenced greatly by many factors. Varieties chosen were one of the most substantial decisions. There is a great difference among sorghum varieties in stalk dimension, yield and its components (Mohamed et al., 2006). Aly et al., (2008) reported that sweet sorghum varieties show significant differences in leaf area, plant height and diameter, percentages of sucrose, purity, juice and syrup extraction, as well as stripped stalk, juice and syrup yields.

The varieties with a high stalk yield, high extractable juice and brix content, connected with resistance to diseases and drought are surpass for biofuel production (Morris, 2006). So, this yield has brilliant prospects and endeavors are required for creating and identifying the varieties having higher sugar content and higher ethanol production potential.

Nitrogen is the element desired in the superior quantities in yield of crops, comprehensive sweet sorghum. Utilization of nitrogen enhanced sugar percentage, root and sugar yield for sugar beet plants (Tsialtas and Maslaris, 2005 and Mekdad and Rady, 2016). Increasing nitrogen enhance significantly yield and quality of sugar beet plants Mekdad (2015). Almodares and Hoseini (2016) noted that the effect of nitrogen levels on stem dimension of sweet sorghum were significant at $1 \%$, as well as produce the maximum values of stem fresh weight and percentage of brix, total sugar, sucrose, purity and ethanol yield of stem.

Application of potassium fertilizers increment yield of (Sorghum biocolor (L.) Moench) especially with increasing levels of nitrogen (Pholsen and Sornsungnoen, 2004). Potassium fertilizer is required for effective transformation of solar energy into chemical energy (Mengel and Kirkby, 2001). Exact use of $\mathrm{N}$ and $\mathrm{K}$ fertilizers can invigorate biomass and starch of sweet sorghum which considered a vital element in food and modern use.

In spite of the fact that the impact of $\mathrm{K}$ fertilizer on different plants is appeared (Adeli and Varco, 2002) however there are few works concerning the impact of $\mathrm{K}$ fertilizer on biomass of sweet sorghum. Therefore, it is of large value to conduct an experiment on yield and sugar content of sweet sorghum in connection to different levels of $\mathrm{N}$ and $\mathrm{K}$ fertilizers as well as the influences of varieties.

Thus, the primary goal of this study was to evaluate the response of two varieties of sweet sorghum to nitrogen and potassium fertilization under arid conditions.

\section{Materials and Methods}

The present investigation was carried out at the farm of the Faculty of Agriculture, Demo $\left(29^{\circ} 17^{`} \mathrm{~N} ; 30^{\circ} 53^{`}\right.$ E), Fayoum University, Egypt, during the two successive summer seasons of 2013 and 2014.The objective of this work was to evaluate two 
sweet sorghum varieties viz., Honey $\left(\mathrm{V}_{1}\right)$ and Brandes $\left(\mathrm{V}_{2}\right)$ under the effect of three nitrogen and potassium fertilizer levels on plant characteristics, quality and yield traits of sweet sorghum.

The experiment was set up according to three-factorial (Split-plot plot) block design in three replications, with the basic plot size of $10.5 \mathrm{~m}^{2}$, each experimental basic unit included 5 ridges, $60 \mathrm{~cm}$ apart and $3.5 \mathrm{~m}$ long, $\left(1 / 400\right.$ fed., fed $=4200 \mathrm{~m}^{2}=0.405$ hectare).

The main plots were assigned to sweet sorghum varieties viz., Honey $\left(\mathrm{V}_{1}\right)$ and Brandes $\left(\mathrm{V}_{2}\right)$. The sub plots were occupied with three levels of nitrogen (ammonium nitrate, $\mathrm{NH}_{4} \mathrm{NO}_{3}(33.5 \% \mathrm{~N})$ at the level of $80\left(\mathrm{~N}_{1}\right), 100\left(\mathrm{~N}_{2}\right)$ and $120\left(\mathrm{~N}_{3}\right)$ in three equal doses i.e., at planting, 4 leaf stage after 21 days from planting and booting stage after 35 days from planting. Potassium sulphate $\left(48 \% \mathrm{~K}_{2} \mathrm{O}\right)$ applied to the soil in granular form at the level of $25\left(\mathrm{~K}_{1}\right), 50\left(\mathrm{~K}_{2}\right)$ and $75\left(\mathrm{~K}_{3}\right) \mathrm{kg} \mathrm{K}_{2} \mathrm{SO}_{4}$ lfed (fed= $4200 \mathrm{~m}^{2}=$ 0.405 hectare) were arranged in the sub-sub plots treatments and applied in three equal doses i.e., after thinning, before the second and the third irrigation (surface irrigation as recommended). Calcium super phosphate $\left(15.5 \% \quad \mathrm{P}_{2} \mathrm{O}_{5}\right)$ at the rate of $200 \mathrm{~kg} / \mathrm{fed}$ was applied during land. Seedlings were thinned at two plants/hill after 21 days from sowing. Other cultural practices such as hoeing, irrigation, etc., were maintained aimed at levels to assure optimum production.

The preceding winter crop was sugar beet (Beta vulgaris, L) in both seasons. After sterilization using $1 \% \quad(\mathrm{v} / \mathrm{v})$ sodium hypochlorite, experiments were sown on May $7^{\text {th }}$ and $5^{\text {th }}$ in the first and second season and harvest was at dough to ripe stage (on August $29^{\text {th }}$ and $26^{\text {st }}$ ) in 2013 and 2014 seasons, respectively. Physical and chemical analysis of soil at the experimental site in both seasons of study are presented in Table (1).The soil is a sandy clay loam in 2013 and sandy loam in 2014, and defined as Typic Torripsamments, siliceous, hyperthermic (Soil Survey Staff, USDA, 1999)

\section{Climatic conditions}

Considering average data for the two experimental seasons, average maximum daily temperature was $\approx 38.98^{\circ} \mathrm{C}$ and the air relative humidity was usually $\approx 43.88 \%$. Table (2) shows the variations of maximum daily temperatures during growth season as average.

At harvest time a random sample of twenty plants from each sub-sub plot was taken to determine the flowing traits. Growth traits: Stem length, stem diameter, stem weight, leaf weight, seed index. Juice quality traits: Stems was taken from each sub-sub plot stripped, cleaned and squeezed by electric roller pilot mill. Brix\%: estimated by using digital refractometer, sucrose $\%$ determined by using direct polarization method as described by A.O.A.C (1995), purity\%: calculated by dividing sucrose \%/T.S.S\% $\mathrm{x} 100$, juice extraction \%: determined by dividing juice weight/stem weight $\mathrm{x} 100$. Yield and its components: Net stripped stem, leaves, grain, sugar and juice yield, the theoretical ethanol yield $\left(1 \mathrm{fed}^{-1}\right.$, fed $=4200$ $\mathrm{m}^{2}=0.405$ hectare) was calculated according to a method described by Lipinski (1978), the ethanol yield = sugar content $($ brix \%) $\times 6.5$ (converting index $) \times 0.85$ (producing index) $\times$ fresh biomass $\left(\mathrm{t}\right.$ fed $^{-}$ ${ }^{1}\left(\mathrm{fed}=4200 \mathrm{~m}^{2}=0.405\right.$ hectare $)$.

Where: converting index is constant (6.5) to explain the efficiency of converting sugar and biomass of stem yield of sweet sorghum to ethanol. Producing index is constant (0.85) to explain the efficiency of 
manufacturing sugar and biomass of stem yield of sweet sorghum to ethanol.

All obtained data were statistically analyzed according to the technique of analysis of variance (ANOVA) for the split-split plot design as published by Gomez and Gomez (1984), using GenStat $12^{\text {th }}$ edition. Least Significant Difference (LSD) method was used to test the differences between treatment means at 5\% level of probability. The data of sugar yield and its components of the study were analyzed by two statistical procedures; stepwise regression was used in order to determine the most important variables contributed to sugar yield variability (Draper and Smith, 1981) and best subsets regression to assess all possible models and displays a subset along with their adjusted R-squared and Mallows' $C_{p}$ values. For this purpose computer software MINITAB (version 16) was used. Where: Mallows' $C_{p}$-statistic, recall that an underspecified model is a model in which important predictors are missing. And, an underspecified model yields biased regression coefficients and biased predictions of the response. Well, in short, Mallows' $C_{p}$-statistic estimates the size of the bias that is introduced into the predicted responses by having an underspecified model.

\section{Results and Discussion}

\section{Effect of sweet sorghum varieties}

The results obtained in Tables (3 and 4) revealed that varieties significantly differed in stem diameter, seed index and theoretical ethanol yield in 2013 and 2014 seasons, stem length, stem and leaf weight in the $1^{\text {th }}$ season, as well as sucrose, purity, juice extraction, stem yield, juice and sugar yield in the $2^{\text {nd }}$. The highest values of former studied traits were recorded by variety
Brandes $\left(\mathrm{V}_{2}\right)$ as compared with the anther variety Honey $\left(\mathrm{V}_{1}\right)$. The differences in these traits between varieties might be due to the differences in their genetic the make-up. Such data in the same trend with Mohamed et al., (2006), Almodares et al., (2008) and EL-Sheikh et al., (2011). The superiority of $\mathrm{cv}$. Brandes in theoretical ethanol yield (1/fed) in both season and sugar yield (ton/fed, fed $=4200 \mathrm{~m}^{2}=0.405$ hectare) in the second season might be due to its high records of mean sucrose, brix, juice extraction and stem yield.

It was noticed that planting Brandes variety $\left(V_{2}\right)$ caused significant increases in stem length $(\mathrm{cm})$ by 10.63 and $7.73 \%$,stem diameter $(\mathrm{cm})$ by 18.99 and $15.68 \%$, stem weight (kg/plant) by 20.00 and 20.69 , leaf weight (kg/plant) by 10.00 and 5.00 , seed index (g) by 4.53 and 3.81, sucrose by 2.73 and $3.88 \%$, purity by 0.61 and $2.78 \%$, juice extraction from fresh stems by 0.44 and $2.52 \%$, stem yield (t/fed) by 5.63 and 6.68 , juice yield $(\mathrm{t} / \mathrm{fed})$ by 6.23 and 9.50 ,also sugar yield ( $\mathrm{t} / \mathrm{fed}$ ) by 8.21 and 10.08 as well as theoretical ethanol yield ( $1 / \mathrm{fed})$ by 8.71 and $10.90 \%$ in the first and second season respectively, compared planting with Honey variety $\left(\mathrm{V}_{1}\right)$ of sweet sorghum. Our results indicated that taller, thicker and heavier sweet sorghum varieties stems could have higher stem, juice and sugar yield and consequently higher theoretical ethanol yield. Theoretical ethanol yield ranged between 1089.60 and $1038.40 \mathrm{l} / \mathrm{fed}$ for Honey variety $\left(\mathrm{V}_{1}\right)$ and 1184.50 and $1151.60 \mathrm{l} /$ fed for Brandes variety $\left(\mathrm{V}_{2}\right)$ in the first and second season, respectively. Meantime, the variation among sweet sorghum ability in theoretical ethanol production detected herein was affirmed previously by Abd El-Razek and Besheit (2009), Almodares and Goli (2013) and Rutto et al., (2013). In general, among the tested varieties of sorghum the most 
productive was Brandes $\left(\mathrm{V}_{2}\right)$, while the Honey $\left(\mathrm{V}_{1}\right)$ was characterized by the lowest productivity.

\section{Effect of nitrogen fertilization}

The results showed that the effect of nitrogen fertilizer was significant at $1 \%$ level on all studied traits in both seasons. The trait means comparison showed that stem length $(\mathrm{cm})$ by 8.92 and $17.88 \%$, diameter $(\mathrm{cm})$ by 10.53 and $29.41 \%$, stem weight by 48.98 and $41.51 \%$, leaf weight by 47.06 and $23.53 \%$, seed index by 11.23 and $8.66 \%$, brix by 7.58 and $7.06 \%$, sucrose by 13.92 and $13.47 \%$, purity by 6.02 and 5.98 $\%$, juice extraction from fresh stems by 5.99 and $5.60 \%$ as well as, stems yield by 14.01 and $16.59 \%$, leaves yield by 29.51 and $37.55 \%$, juice yield by 20.84 and $23.17 \%$, also sugar yield by 29.51 and $31.62 \%$ were significantly increased with increasing in nitrogen fertilizer levels from 80 to $120 \mathrm{~kg}$ $\mathrm{N} / \mathrm{fed}$ in the first and second season respectively. The mean comparison of the nitrogen fertilizer levels on the above measurements is presented in Tables( 3 and 4). Results showed that all former traits were increased significantly by increasing nitrogen fertilizer levels from 80 to $120 \mathrm{~kg}$ $\mathrm{N} / \mathrm{fed}$. The remained measurements were highest under nitrogen level $120 \mathrm{~kg} \mathrm{~N} / \mathrm{fed}$. Our results indicated that taller, thicker and heavier sweet sorghum stems could have higher stem, juice and sugar yield and, consequently, higher theoretical ethanol yield. The results for stem height and diameter are quite in line with those of Almodares et al., (2008) and Usofzadeh et al., (2013), reported that nitrogen fertilization increased stem height and stem diameter, as well as stem, sugar, juice and theoretical ethanol yield. Nitrogen may affect plant growth through cell division and cell enlargement which consequently increase stem height and diameter, consequently, higher yield. These results indicate that $\mathrm{N}$ input of $120 \mathrm{~kg} \mathrm{~N}$ fed ${ }^{1}$ is sufficient to obtain maximum stems, leaves, sugar and theoretical ethanol yields, while the further application of $\mathrm{N}$ fertilizer poses a risk of having negative effects on sweet sorghum production. Uchino et al. (2013) observed similar results and reported that the yield of sweet sorghum increased at up to $150 \mathrm{~kg} \mathrm{~N} \mathrm{ha}{ }^{-1}$. Root and sugar yield in sugar beet plants were increased with increasing nitrogen level (Mekdad, 2015).

\section{Effect of potassium fertilization}

A significant effect at $1 \%$ level was detected due to potassium levels on stem length and diameter, stem and leaf weight, seed index, percentage of brix, sucrose purity and juice extraction, as well as yields in terms of stems, leaves, juice, sugar and theoretical ethanol in 2013 and 2014 seasons. Increasing potassium up to $75 \mathrm{~kg} \mathrm{~K}_{2} \mathrm{O}$ /fed from $0 \mathrm{~kg} \mathrm{~K} 2 \mathrm{O} /$ fed $\left(\mathrm{K}_{1}\right)$ increased all studied traits. The mean comparison of the potassium fertilizer levels on the above measurements is presented in Table ( 3 and 4). It was noticed that applying $75 \mathrm{~kg}$ $\mathrm{K}_{2} \mathrm{O} /$ fed $\left(\mathrm{K}_{3}\right)$ caused significant increases in stem length $\left(\mathrm{cm}^{2}\right) 8.92$ and $7.18 \%$, stem diameter $(\mathrm{cm}) 10.53$ and $9.47 \%$, stem weight (kg/plant) 12.28and15.00\%, leaf weight (kg/plant) 15.00and15.79 \%, seed index4.32and $2.74 \%$, brix 2.51 and $2.32 \%$, sucrose 5.08 and $4.23 \%$, purity 2.59 and 1.86 $\%$, juice extraction 1.76 and $1.63 \%$, stem yield $\left(\mathrm{t} / \mathrm{fed}, \mathrm{fed}=4200 \mathrm{~m}^{2}=0.405\right.$ hectare $)$ 5.96 and5.35 \%, leaves yield (t/fed) 9.45and12.25 \%,juice yield $(\mathrm{t} / \mathrm{fed})$ 7.96and7.16\%, sugar yield (t/fed) 10.53 and $9.23 \%$ and theoretical ethanol yield (l/fed) 11.56 and $9.82 \%$ in the first and second season respectively compared with $0 \mathrm{~kg}$ $\mathrm{K}_{2} \mathrm{O} / \mathrm{fed}\left(\mathrm{K}_{1}\right)$. Overall, potassium fertilizer application of $75 \mathrm{~kg} \mathrm{~K} / \mathrm{fed}\left(\mathrm{K}_{3}\right)$ recorded the highest values for all studied traits. Such 
increase in stem yield obtained from using potassium with level of $75 \mathrm{~kg} \mathrm{~K} 2 \mathrm{O} / \mathrm{fed}$ can be attributed to enhance sweet sorghum growth, in terms of longer, thicker and heavier stems weight, whereas $\mathrm{K}$ plays a major role in many physiological and biochemical processes such as cell division and elongation. These results are in accordance with those reported by Almodares et al., (2008) and EL-Sheikh et al., (2011).

The positive effect of $\mathrm{K}$ fertilizer which improved chemical components may be due to the vital role of $\mathrm{K}$ in building up metabolites and activating starch synthetase enzymes and carbohydrates accumulation (Nitoses and Evans, 1969).

\section{D- Interaction effects}

D-1. Effect of the bilateral interaction between the two sweet sorghum varieties and nitrogen levels: Data illustrated in Tables (3 and 4) revealed that the mean sugar yield $\left(\mathrm{t} / \mathrm{fed}\right.$, fed $=4200 \mathrm{~m}^{2}=0.405$ hectare) and theoretical ethanol yield (1/fed) in both seasons, while juice extraction \% and juice yield ( $t / f e d)$ in the first season, as well as stem weight (kg/plant) and sucrose $\%$ in the second season were significantly affected by the interaction between application of the two sweet sorghum varieties and nitrogen levels. The highest values of former studied traits were recorded by variety Brandes $\left(\mathrm{V}_{2}\right)$ with higher level of nitrogen $120 \mathrm{~kg} \mathrm{~N} / \mathrm{fed}$. Reddy et al., (2008), found that the interaction between nitrogen fertilizer and varieties were significant forjuice extract $\left(\mathrm{gm}^{-2}\right)$ and sugar yield $(\mathrm{t}$ ha $\left.{ }^{1}\right)$.

D-2. Effect of the bilateral interaction between the two sweet sorghum varieties and potassium levels: Results in Tables (3 and 4 ) indicated that sugar yield (t/fed) in both seasons, while seed index, stem yield ( $\mathrm{t} /$ fed, $\mathrm{fed}=4200 \mathrm{~m}^{2}=0.405$ hectare), juice yield $(\mathrm{t} / \mathrm{fed})$ and theoretical ethanol yield $(1 /$ fed) in the first season, as well stem weight $(\mathrm{kg} / \mathrm{plant})$ in the second season were significantly affected by the interaction between application of the two sweet sorghum varieties and potassium fertilizer levels. The highest amounts of aforementioned characters were obtained with the application of variety Brandes $\left(\mathrm{V}_{2}\right)$ with higher level of potassium $75 \mathrm{~kg} \mathrm{~K} / \mathrm{fed}$. Almodares et al. (2008), reported that the interaction between potassium fertilizer and varieties was significant for sugar yield $(\mathrm{t}$ $\left.\mathrm{ha}^{-1}\right)$.

D-3. Effect of the bilateral interaction between levels of nitrogen and potassium fertilizer: Data illustrated in Tables (3 and 4) reveal that the mean of stem yield ( $\mathrm{t} / \mathrm{fed}$, fed $=4200 \mathrm{~m}^{2}=0.405$ hectare), sucrose $\%$, sugar and juice yield (t/fed) and theoretical ethanol yield (1/fed) in both seasons, besides seed index and juice extraction $\%$ in the first season, in addition to, stem weight (kg/plant) and leaves yield (t/fed) in the second one were significantly affected by the interaction between application of nitrogen and potassium levels. The highest amounts of aforementioned characters were obtained with higher level of nitrogen 120 $\mathrm{kg} \mathrm{N} / \mathrm{fed}$ and potassium $75 \mathrm{~kg} \mathrm{~K} / \mathrm{fed}$. Almodares et al., (2008), noted that the interaction between nitrogen and potassium fertilizer level was significant for stem height $(\mathrm{cm})$ and stem fresh weight $\left(\mathrm{t} \mathrm{ha}^{-1}\right)$.

D-4. Effect of the trilateral interaction among the two sweet sorghum varieties, nitrogen and potassium levels: The data presented in Tables ( 3 and 4) show the differences seed index in 2013 and 2014 seasons, besides brix, juice extraction \%, sugar and juice yield ( $\mathrm{t} / \mathrm{fed}$, fed $=4200 \mathrm{~m}^{2}=$ 0.405 hectare) in the first season, while stem 
length $(\mathrm{cm})$, leaf weight $(\mathrm{kg} / \mathrm{plant})$, leaves yield ( $t / f e d)$ in the second season due to the interaction among the three factors were significant. The highest yields of sugar and juice were 1.83 and $10.68 \mathrm{t} / \mathrm{fed}$ in the first season, respectively which are presented in Fig.(1\&2) were obtained by Brandes $\left(\mathrm{V}_{2}\right)$ variety with higher level of nitrogen $120 \mathrm{~kg}$ $\mathrm{N} / \mathrm{fed}$ and potassium $75 \mathrm{~kg} \mathrm{~K} / \mathrm{fed}$.(fed $=4200$ $\mathrm{m}^{2}=0.405$ hectare).

\section{Stepwise regression and best-subsets regression}

Stepwise regression and best-subsets regression are both automatic tools that help you identify useful predictors during the exploratory stages of model building for linear regression. These two procedures use different methods and present you with different output. In stepwise regression analysis, sugar yield (Y) as dependent variable and other traits as independent variables were considered.

The results showed that stem yield $\left(\mathrm{X}_{5}\right)$, juice extraction\% $\left(\mathrm{X}_{10}\right)$, brix $\%\left(\mathrm{X}_{7}\right)$, stem weight $\left(\mathrm{X}_{4}\right)$, leaves weight $\left(\mathrm{X}_{3}\right)$ and leaves yield $\left(\mathrm{X}_{6}\right)$ with $\mathrm{R}^{2}=99.87 \%$ in the $1^{\text {st }}$ season, and stem yield $\left(\mathrm{X}_{5}\right)$, brix\% $\left(\mathrm{X}_{7}\right)$, juice extraction $\left(\mathrm{X}_{10}\right)$, stem weight $\left(\mathrm{X}_{4}\right)$, stem diameter $\left(\mathrm{X}_{2}\right)$ and leaves weight $\left(\mathrm{X}_{3}\right)$ with $\mathrm{R}^{2}=99.88 \%$ in the $2^{\text {nd }}$ season, had justified the maximum of sugar yield changes.

Table.1 Particle size distribution and some chemical properties of the experimental soil in 2013and 2014seasons

\begin{tabular}{|c|c|c|c|c|}
\hline \multicolumn{3}{|c|}{ Season } & 2013 & 2014 \\
\hline \multicolumn{3}{|c|}{ Sand\% } & 65.9 & 79.4 \\
\hline \multicolumn{3}{|c|}{ Silt\% } & 6.9 & 8.7 \\
\hline \multicolumn{3}{|c|}{ Clay\% } & 27.2 & 11.9 \\
\hline \multicolumn{3}{|c|}{ Soil texture class } & Sandy clay Loam & Sandy Loam \\
\hline \multicolumn{3}{|c|}{$\mathrm{CaCO3 \%}$} & 10.11 & 8.64 \\
\hline \multirow[t]{4}{*}{ Cations } & \multirow{8}{*}{$\operatorname{MeqL}^{-1}$} & $\mathrm{Na}^{+}$ & 13.8 & 12.4 \\
\hline & & $\mathbf{K}^{+}$ & 3.9 & 2.57 \\
\hline & & $\mathrm{Mg}^{+2}$ & 30.4 & 27.61 \\
\hline & & $\mathrm{Ca}^{+2}$ & 58.6 & 63.11 \\
\hline \multirow[t]{4}{*}{ Anions } & & $\mathrm{SO4}^{-2}$ & 62 & 37.99 \\
\hline & & $\mathrm{CL}^{-}$ & 159 & 167 \\
\hline & & HCO3 & 9.9 & 12.3 \\
\hline & & $\mathrm{CO3}^{-2}$ & - & - \\
\hline \multicolumn{3}{|c|}{ Organic Matter \% } & 0.82 & 0.54 \\
\hline \multicolumn{3}{|c|}{ ECe, $\mathrm{dSm}^{-1}$ at $25 \mathrm{C}^{\circ}$} & 14.8 & 13.2 \\
\hline \multicolumn{3}{|c|}{ pH at $25 \mathrm{C}^{\circ}$} & 7.60 & 7.93 \\
\hline \multirow{4}{*}{\multicolumn{2}{|c|}{$\begin{array}{l}\text { Micronutrients } \\
\text { (ppm) }\end{array}$}} & $\mathbf{F e}$ & 12.51 & 9.47 \\
\hline & & Mn & 3.41 & 1.76 \\
\hline & & $\mathbf{C u}$ & 0.52 & 0.24 \\
\hline & & $\mathbf{Z n}$ & 0.94 & 0.38 \\
\hline
\end{tabular}


Table.2 Monthly weather data at Fayoum, Egypt as average during 2013-2014

\begin{tabular}{ccccc}
\hline Month & ${ }^{\mathrm{a}} \mathrm{T}_{\min }\left({ }^{\circ} \mathrm{C}\right)$ & $\mathrm{T}_{\max }\left({ }^{\circ} \mathrm{C}\right)$ & $\mathrm{T}_{\mathrm{avg}}\left({ }^{\circ} \mathrm{C}\right)$ & $\mathrm{RH}_{\mathrm{avg}}(\%)$ \\
\hline May & 21.1 & 38.0 & 29.55 & 41.8 \\
June & 23.4 & 39.1 & 31.25 & 43.8 \\
July & 25.2 & 39.0 & 32.10 & 45.3 \\
August & 25.3 & 39.8 & 32.55 & 44.6 \\
\hline
\end{tabular}

${ }^{\mathrm{a}} \mathrm{T}_{\mathrm{avg}}, \mathrm{T}_{\max }$ and $\mathrm{T}_{\min }$ are average, maximum and minimum temperatures, respectively,

$\mathrm{RH}_{\mathrm{avg}}$ is average relative humidity.

Table.3 Effects of cultivars, nitrogen and potassium levels and their interactions on sweet sorghum growth and yields in two seasons

\begin{tabular}{|c|c|c|c|c|c|c|c|c|}
\hline \multirow{2}{*}{\multicolumn{2}{|c|}{ Treatment }} & $\begin{array}{c}\text { Stem } \\
\text { length }\end{array}$ & $\begin{array}{c}\text { Stem } \\
\text { diameter }\end{array}$ & $\begin{array}{c}\text { Stem } \\
\text { weight }\end{array}$ & $\begin{array}{c}\text { Leaf } \\
\text { weight }\end{array}$ & Seed index & Stem yield & $\begin{array}{c}\text { Leaves } \\
\text { yield }\end{array}$ \\
\hline & & $(\mathrm{m})$ & $(\mathrm{cm})$ & \multicolumn{2}{|c|}{ (kg/plant) } & (g) & \multicolumn{2}{|c|}{$(\mathrm{t} / \mathrm{fed})$} \\
\hline \multicolumn{9}{|c|}{2013} \\
\hline \multirow{3}{*}{ Varieties } & Honey $\left(V_{1}\right)$ & 3.67 & 2.37 & 0.55 & 0.20 & 24.97 & 21.50 & 6.37 \\
\hline & Brandes $\left(V_{2}\right)$ & 4.06 & 2.82 & 0.66 & 0.22 & 26.10 & 22.71 & 6.91 \\
\hline & LSD (5\%) & $0.31 *$ & $0.21 *$ & $0.07 *$ & $0.01 * *$ & $0.89 *$ & $\mathrm{~ns}$ & ns \\
\hline \multirow{4}{*}{ Nitrogen } & $80 \mathrm{Kg} \mathrm{N} / \mathrm{fed}\left(\mathrm{N}_{1}\right)$ & 3.55 & 2.27 & 0.49 & 0.17 & 24.22 & 20.70 & 5.76 \\
\hline & $100 \mathrm{Kg} \mathrm{N} / \mathrm{fed}\left(\mathrm{N}_{2}\right)$ & 3.88 & 2.59 & 0.60 & 0.21 & 25.45 & 22.00 & 6.70 \\
\hline & $120 \mathrm{Kg} \mathrm{N} / \mathrm{fed}\left(\mathrm{N}_{3}\right)$ & 4.17 & 2.93 & 0.73 & 0.25 & 26.94 & 23.60 & 7.46 \\
\hline & $\operatorname{LSD}(5 \%)$ & $\begin{array}{c}0.18 * \\
*\end{array}$ & $0.14 * *$ & $0.03 * *$ & $0.01 * *$ & $0.22 * *$ & $0.41 * *$ & $0.23 * *$ \\
\hline \multirow{4}{*}{ Potassium } & $25 \mathrm{Kg} \mathrm{K} / \mathrm{fed}(\mathrm{K} 1)$ & 3.70 & 2.47 & 0.57 & 0.20 & 25.01 & 21.49 & 6.35 \\
\hline & $50 \mathrm{Kg} \mathrm{K} / \mathrm{fed}(\mathrm{K} 2)$ & 3.87 & 2.59 & 0.61 & 0.21 & 25.50 & 22.05 & 6.63 \\
\hline & $75 \mathrm{Kg} \mathrm{K/fed} \mathrm{(K3)}$ & 4.03 & 2.73 & 0.64 & 0.23 & 26.09 & 22.77 & 6.95 \\
\hline & LSD (5\%) & $\begin{array}{c}0.10 * \\
*\end{array}$ & $0.04 * *$ & $0.01 * *$ & $0.01 * *$ & $0.13 * *$ & $0.21 * *$ & $0.18 * *$ \\
\hline \multirow{4}{*}{ Interactions } & $\mathbf{V} * \mathbf{N}$ & ns & ns & ns & ns & ns & ns & ns \\
\hline & $\mathbf{V} * \mathbf{K}$ & ns & ns & ns & ns & $* *$ & $* *$ & ns \\
\hline & $\mathbf{N}^{*} \mathbf{K}$ & ns & ns & ns & ns & $* *$ & $*$ & ns \\
\hline & $\mathbf{V} * \mathbf{N} * \mathbf{K}$ & ns & ns & ns & ns & $* *$ & ns & ns \\
\hline \multicolumn{9}{|c|}{2014} \\
\hline \multirow[t]{2}{*}{ Varieties } & Honey $\left(\mathbf{V}_{1}\right)$ & 3.75 & 2.36 & 0.58 & 0.20 & 24.40 & 20.80 & 6.08 \\
\hline & Brandes $\left(V_{2}\right)$ & 4.04 & 2.73 & 0.70 & 0.21 & 25.33 & 22.19 & 6.89 \\
\hline \multirow{4}{*}{ Nitrogen } & LSD (5\%) & ns & $0.37 *$ & ns & ns & $0.83 *$ & $0.19 * *$ & Ns \\
\hline & $80 \mathrm{Kg} \mathrm{N} / \mathrm{fed}\left(\mathrm{N}_{1}\right)$ & 3.58 & 2.21 & 0.53 & 0.17 & 23.80 & 19.83 & 5.46 \\
\hline & $100 \mathrm{Kg} \mathrm{N} / \mathrm{fed}\left(\mathrm{N}_{2}\right)$ & 3.88 & 2.56 & 0.64 & 0.21 & 24.93 & 21.53 & 6.48 \\
\hline & $120 \mathrm{Kg} \mathrm{N} / \mathrm{fed}\left(\mathrm{N}_{3}\right)$ & 4.22 & 2.86 & 0.75 & 0.21 & 25.86 & 23.12 & 7.51 \\
\hline \multirow{4}{*}{ Potassium } & LSD (5\%) & $0.14^{* *}$ & $0.06^{* *}$ & $0.02 * *$ & $0.01 * *$ & $0.18 * *$ & $0.30 * *$ & $0.16^{* *}$ \\
\hline & $25 \mathrm{Kg} \mathrm{K} / \mathrm{fed}(\mathrm{K1})$ & 3.76 & 2.43 & 0.60 & 0.19 & 24.49 & 20.95 & 6.12 \\
\hline & $50 \mathrm{Kg} \mathrm{K} / \mathrm{fed}(\mathrm{K} 2)$ & 3.89 & 2.54 & 0.64 & 0.21 & 24.93 & 21.45 & 6.47 \\
\hline & $75 \mathrm{Kg} \mathrm{K} / \mathrm{fed}(\mathrm{K3})$ & 4.03 & 2.66 & 0.69 & 0.22 & 25.16 & 22.07 & 6.87 \\
\hline \multirow{5}{*}{$\begin{array}{c}\text { Interaction } \\
\mathrm{s}\end{array}$} & LSD (5\%) & $0.04 * *$ & $0.04 * *$ & $0.01 * *$ & $0.01 * *$ & $0.13 * *$ & $0.11 * *$ & $0.07 * *$ \\
\hline & $\mathbf{V} * \mathbf{N}$ & ns & ns & $* *$ & ns & ns & ns & ns \\
\hline & $\mathbf{V} * \mathbf{K}$ & ns & ns & $* *$ & ns & ns & ns & ns \\
\hline & $\mathbf{N} * \mathbf{K}$ & ns & ns & $* *$ & ns & ns & $* *$ & $* *$ \\
\hline & $\mathbf{V} * \mathbf{N} * \mathbf{K}$ & $* *$ & ns & ns & $*$ & $*$ & ns & $* *$ \\
\hline
\end{tabular}

$* \mathrm{P}<0.05 ; * * \mathrm{P}<0.01 ; \mathrm{ns}-$ non-significant 
Table.4 Effects of cultivars, nitrogen and potassium levels and their interactions on sweet sorghum growth and yields in two seasons

\begin{tabular}{|c|c|c|c|c|c|c|c|c|}
\hline \multirow{2}{*}{\multicolumn{2}{|c|}{ Treatment }} & Brix & Sucrose & Purity & $\begin{array}{c}\text { Juice } \\
\text { extraction }\end{array}$ & $\begin{array}{c}\text { Sugar } \\
\text { yield }\end{array}$ & Juice yield & $\begin{array}{l}\text { Ethanol } \\
\text { yield }\end{array}$ \\
\hline & & \multirow{2}{*}{\multicolumn{4}{|c|}{$\frac{\%}{2013}$}} & \multicolumn{2}{|c|}{$(\mathrm{t} / \mathrm{fed})$} & (1/fed.) \\
\hline & & & & & & \multicolumn{2}{|c|}{ (17ivi) } & \\
\hline Varieties & Honey $\left(V_{1}\right)$ & 15.97 & 9.15 & 57.24 & 38.80 & 1.34 & 8.35 & 1089.60 \\
\hline \multirow{6}{*}{ Nitrogen } & Brandes $\left(V_{2}\right)$ & 16.31 & 9.40 & 57.59 & 38.97 & 1.45 & 8.87 & 1184.50 \\
\hline & LSD (5\%) & ns & ns & ns & ns & ns & ns & $80.32 *$ \\
\hline & $80 \mathrm{Kg} \mathrm{N} / \mathrm{fed}\left(\mathrm{N}_{1}\right)$ & 15.57 & 8.69 & 55.78 & 37.76 & 1.22 & 7.82 & 994.00 \\
\hline & $100 \mathrm{Kg} \mathrm{N} / \mathrm{fed}\left(\mathrm{N}_{2}\right)$ & 16.11 & 9.24 & 57.33 & 38.86 & 1.38 & 8.55 & 1123.90 \\
\hline & $120 \mathrm{Kg} N / \mathrm{fed}\left(\mathrm{N}_{3}\right)$ & 16.75 & 9.90 & 59.14 & 40.02 & 1.58 & 9.45 & 1293.20 \\
\hline & LSD (5\%) & $\begin{array}{c}0.06^{*} \\
*\end{array}$ & $0.07 * *$ & $0.52 * *$ & $0.24 * *$ & $0.03 * *$ & $0.18 * *$ & $23.51 * *$ \\
\hline \multirow[t]{4}{*}{ Potassium } & $25 \mathrm{Kg} \mathrm{K} / \mathrm{fed}(\mathrm{K} 1)$ & 15.94 & 9.06 & 56.78 & 38.55 & 1.33 & 8.29 & 1078.50 \\
\hline & $50 \mathrm{Kg}$ K/fed (K2) & 16.15 & 9.25 & 57.21 & 38.86 & 1.39 & 8.58 & 1129.30 \\
\hline & $75 \mathrm{Kg} \mathrm{K/fed} \mathrm{(K3)}$ & 16.34 & 9.52 & 58.25 & 39.23 & 1.47 & 8.95 & 1203.20 \\
\hline & $\operatorname{LSD}(5 \%)$ & $\begin{array}{c}0.05 * \\
*\end{array}$ & $0.07 * *$ & $0.48 * *$ & $0.16^{* *}$ & $0.02 * *$ & $0.10 * *$ & $16.19 * *$ \\
\hline \multirow[t]{4}{*}{ Interactions } & $\mathbf{V} * \mathbf{N}$ & ns & ns & ns & $*$ & $* *$ & $*$ & $*$ \\
\hline & $\mathbf{V}^{*} \mathbf{K}$ & ns & ns & ns & ns & $* *$ & $* *$ & $*$ \\
\hline & $\mathbf{N} * \mathbf{K}$ & ns & $* *$ & ns & $* *$ & $* *$ & $* *$ & $* *$ \\
\hline & $\mathbf{V} * \mathbf{N} * \mathbf{K}$ & $*$ & ns & ns & $* *$ & $* *$ & $*$ & ns \\
\hline \multicolumn{9}{|c|}{2014} \\
\hline \multirow[t]{3}{*}{ Varieties } & Honey $\left(V_{1}\right)$ & 16.03 & 9.01 & 56.16 & 38.43 & 1.29 & 8.00 & 1038.40 \\
\hline & Brandes $\left(\mathbf{V}_{2}\right)$ & 16.21 & 9.36 & 57.72 & 39.40 & 1.42 & 8.76 & 1151.60 \\
\hline & LSD (5\%) & N.S. & $0.29 *$ & $0.09 * *$ & $0.12 * *$ & $0.04 * *$ & $0.04 * *$ & $30.16 * *$ \\
\hline \multirow[t]{4}{*}{ Nitrogen } & $80 \mathrm{Kg} \mathrm{N} / \mathrm{fed}\left(\mathrm{N}_{1}\right)$ & 15.57 & 8.61 & 55.31 & 37.87 & 1.17 & 7.51 & 944.00 \\
\hline & $100 \mathrm{Kg} N / \mathrm{fed}\left(\mathrm{N}_{2}\right)$ & 16.11 & 9.17 & 56.89 & 38.90 & 1.35 & 8.38 & 1091.80 \\
\hline & $120 \mathrm{Kg} \mathrm{N} / \mathrm{fed}\left(\mathrm{N}_{3}\right)$ & 16.67 & 9.77 & 58.62 & 39.99 & 1.54 & 9.25 & 1249.20 \\
\hline & $\operatorname{LSD}(5 \%)$ & $\begin{array}{c}0.10^{*} \\
*\end{array}$ & $0.08 * *$ & $0.70 * *$ & $0.20 * *$ & $0.02 * *$ & $0.13 * *$ & $20.83 * *$ \\
\hline \multirow[t]{4}{*}{ Potassium } & 25 Kg K/fed (K1) & 15.94 & 8.99 & 56.37 & 38.61 & 1.30 & 8.10 & 1044.90 \\
\hline & $50 \mathrm{Kg} \mathrm{K/fed} \mathrm{(K2)}$ & 16.10 & 9.19 & 57.02 & 38.90 & 1.35 & 8.36 & 1092.60 \\
\hline & $75 \mathrm{Kg} \mathrm{K/fed} \mathrm{(K3)}$ & 16.31 & 9.37 & 57.42 & 39.24 & 1.42 & 8.68 & 1147.50 \\
\hline & LSD (5\%) & $\begin{array}{c}0.05 * \\
*\end{array}$ & $0.04 * *$ & $0.35 * *$ & $0.12 * *$ & $0.01 * *$ & $0.05 * *$ & $8.51 * *$ \\
\hline \multirow[t]{4}{*}{ Interactions } & $\mathbf{V} * \mathbf{N}$ & ns & $*$ & ns & ns & $*$ & ns & $*$ \\
\hline & $\mathbf{V} * \mathbf{K}$ & ns & ns & ns & ns & $*$ & ns & ns \\
\hline & $\mathbf{N} * \mathbf{K}$ & ns & $*$ & ns & ns & $* *$ & $* *$ & $* *$ \\
\hline & $\mathbf{V} * \mathbf{N} * \mathbf{K}$ & ns & ns & ns & ns & ns & ns & ns \\
\hline
\end{tabular}


Table.5 The best-subset regression models by adjusted coefficient of determination, Mallows Cp and standard error estimated of ten traits in sweet corn

\begin{tabular}{|c|c|c|c|c|c|c|c|c|c|c|c|c|c|}
\hline Vars & $\begin{array}{l}\text { Adj. } \\
\text { R-Sq }\end{array}$ & $\begin{array}{c}\text { Mallows } \\
\text { C-p }\end{array}$ & $\begin{array}{c}\text { Standard } \\
\text { error }\end{array}$ & $\begin{array}{l}\text { Stem } \\
\text { height } \\
(\mathrm{cm})\end{array}$ & $\begin{array}{c}\text { Stem } \\
\text { diameter } \\
(\mathrm{cm})\end{array}$ & $\begin{array}{c}\begin{array}{c}\text { Leaves } \\
\text { weight } \\
\text { (kg/plant) }\end{array} \\
\end{array}$ & $\begin{array}{c}\begin{array}{c}\text { Stem } \\
\text { weight } \\
\text { (kg/plant) }\end{array} \\
\end{array}$ & $\begin{array}{l}\begin{array}{l}\text { Stem } \\
\text { yield } \\
\text { (tffed })\end{array} \\
\end{array}$ & $\begin{array}{c}\text { Leaves } \\
\text { yield } \\
\text { (t/fed) }\end{array}$ & Brix $\%$ & Sucrose $\%$ & Purity\% & $\begin{array}{c}\text { Juice extraction } \\
\% \\
\end{array}$ \\
\hline \multicolumn{14}{|c|}{$1^{\text {st }}$ season $(2013)$} \\
\hline 1 & 96.90 & 2800.50 & 0.0314 & & & & & $\mathrm{X}$ & & & & & \\
\hline 2 & 99.40 & 432.60 & 0.0130 & & & & & $\mathrm{X}$ & & & & & $\mathrm{X}$ \\
\hline 3 & 99.70 & 136.90 & 0.0081 & & & & & $\mathrm{X}$ & & $\mathrm{X}$ & & & $\mathrm{X}$ \\
\hline 4 & 99.70 & 106.20 & 0.0074 & & & & & $\mathrm{X}$ & & & $\mathrm{X}$ & $\mathrm{X}$ & $\mathrm{X}$ \\
\hline 5 & 99.80 & 26.30 & 0.0051 & & & & & $\mathrm{X}$ & & $\mathrm{X}$ & $\mathrm{X}$ & $\mathrm{X}$ & $\mathrm{X}$ \\
\hline 6 & 99.80 & 13.40 & 0.0045 & & & & $\mathrm{X}$ & $\mathrm{X}$ & & $\mathrm{X}$ & $\mathrm{X}$ & $\mathrm{X}$ & $\mathrm{X}$ \\
\hline 7 & 99.80 & 10.20 & 0.0043 & & $\mathrm{X}$ & & $\mathrm{X}$ & $\mathrm{X}$ & & $\mathrm{X}$ & $X$ & $\mathrm{X}$ & $\mathrm{X}$ \\
\hline 8 & 99.80 & 7.20 & 0.0041 & $\mathrm{X}$ & $\mathrm{X}$ & & $\mathrm{X}$ & $\mathrm{X}$ & & $\mathrm{X}$ & $\mathrm{X}$ & $\mathrm{X}$ & $\mathrm{X}$ \\
\hline 9 & 99.80 & 9.00 & 0.0042 & $\mathrm{X}$ & $\mathrm{X}$ & $\mathrm{X}$ & $\mathrm{X}$ & $\mathrm{X}$ & & $\mathrm{X}$ & $\mathrm{X}$ & $\mathrm{X}$ & $\mathrm{X}$ \\
\hline 10 & 99.80 & 11.00 & 0.0042 & $\mathrm{X}$ & $\mathrm{X}$ & $X$ & $X$ & $\mathrm{X}$ & $\mathrm{X}$ & $\mathrm{X}$ & $\mathrm{X}$ & $\mathrm{X}$ & $\mathrm{X}$ \\
\hline \multicolumn{14}{|c|}{$2^{\text {nd }}$ season $(2014)$} \\
\hline 1 & 97.80 & 2234.10 & 0.0259 & & & & & $X$ & & & & & \\
\hline 2 & 99.00 & 887.80 & 0.0167 & & & & & $\mathrm{X}$ & & $\mathrm{X}$ & & & \\
\hline 3 & 99.70 & 184.40 & 0.0084 & & & & & $\mathrm{X}$ & & $\mathrm{X}$ & & & $\mathrm{X}$ \\
\hline 4 & 99.70 & 132.30 & 0.0074 & & & & & $\mathrm{X}$ & & & $\mathrm{X}$ & $X$ & $X$ \\
\hline 5 & 99.80 & 14.40 & 0.0042 & & & & & $\mathrm{X}$ & & $X$ & $\mathrm{X}$ & $X$ & $X$ \\
\hline 6 & 99.80 & 12.10 & 0.0041 & $X$ & & & & $X$ & & $X$ & $X$ & $X$ & $X$ \\
\hline 7 & 99.90 & 6.50 & 0.0038 & & $X$ & & $X$ & $X$ & & $X$ & $X$ & $X$ & $X$ \\
\hline 8 & 99.90 & 7.60 & 0.0038 & $\mathrm{X}$ & $X$ & & $X$ & $\mathrm{X}$ & & $X$ & $X$ & $\mathrm{X}$ & $X$ \\
\hline 9 & 99.90 & 9.20 & 0.0039 & $X$ & $X$ & $X$ & $X$ & $X$ & & $X$ & $X$ & $X$ & $X$ \\
\hline 10 & 99.90 & 11.00 & 0.0039 & $\mathrm{X}$ & $\mathrm{X}$ & $X$ & $X$ & $X$ & $\mathrm{X}$ & $X$ & $\mathrm{X}$ & $\mathrm{X}$ & $X$ \\
\hline
\end{tabular}

Vars: refer to how many predictors are in the model

Fig.1 Effect of interactions between varieties, nitrogen and potassium levels on juice yield (t/fed.) in 2013 seasons. Haney V1, Brandes V2, 80 N1, 100 N2, 120 N3 kg N/fed, 25 K1, 50 K2, 75 K3 kg K2SO4lfed.

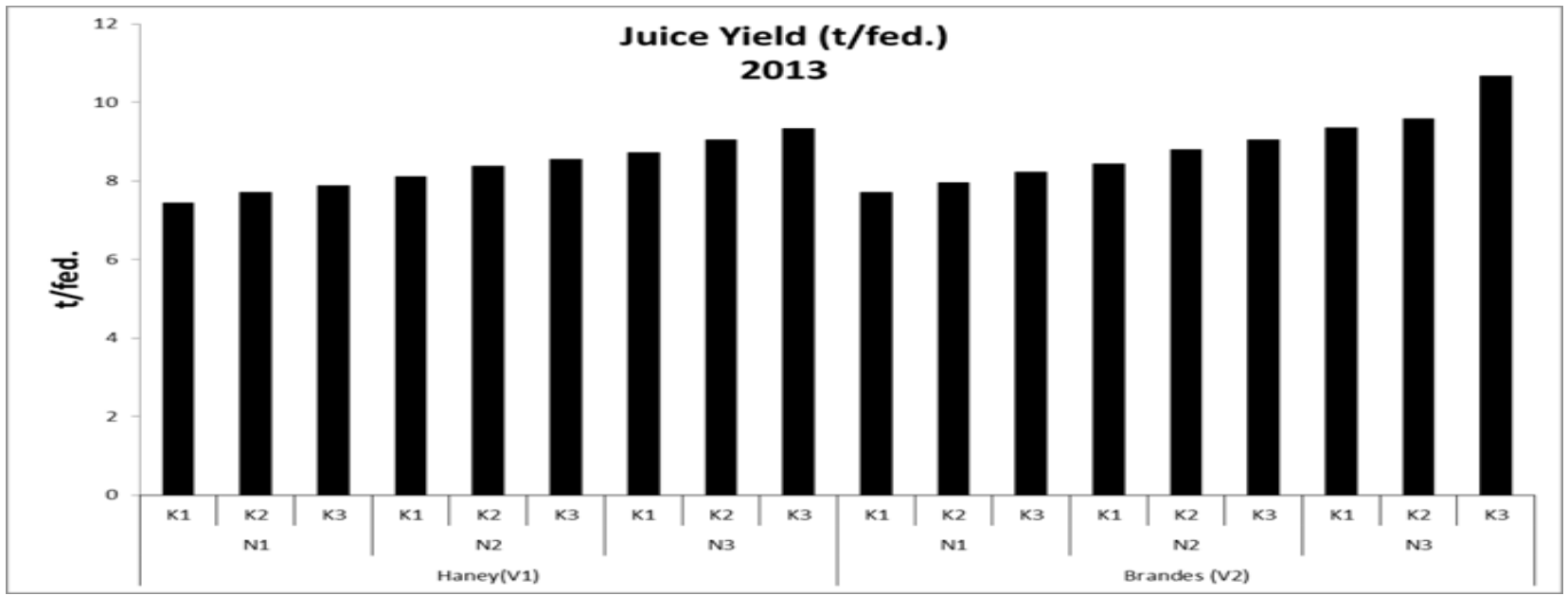


Fig.2 Effect of interactions between varieties, nitrogen and potassium levels on sugar yield (t/fed.) in 2013 seasons. Haney V1, Brandes V2, 80 N1, 100 N2, 120 N3 kg N/fed, 25 K1, 50 K2, 75 K3 kg K2SO4lfed.

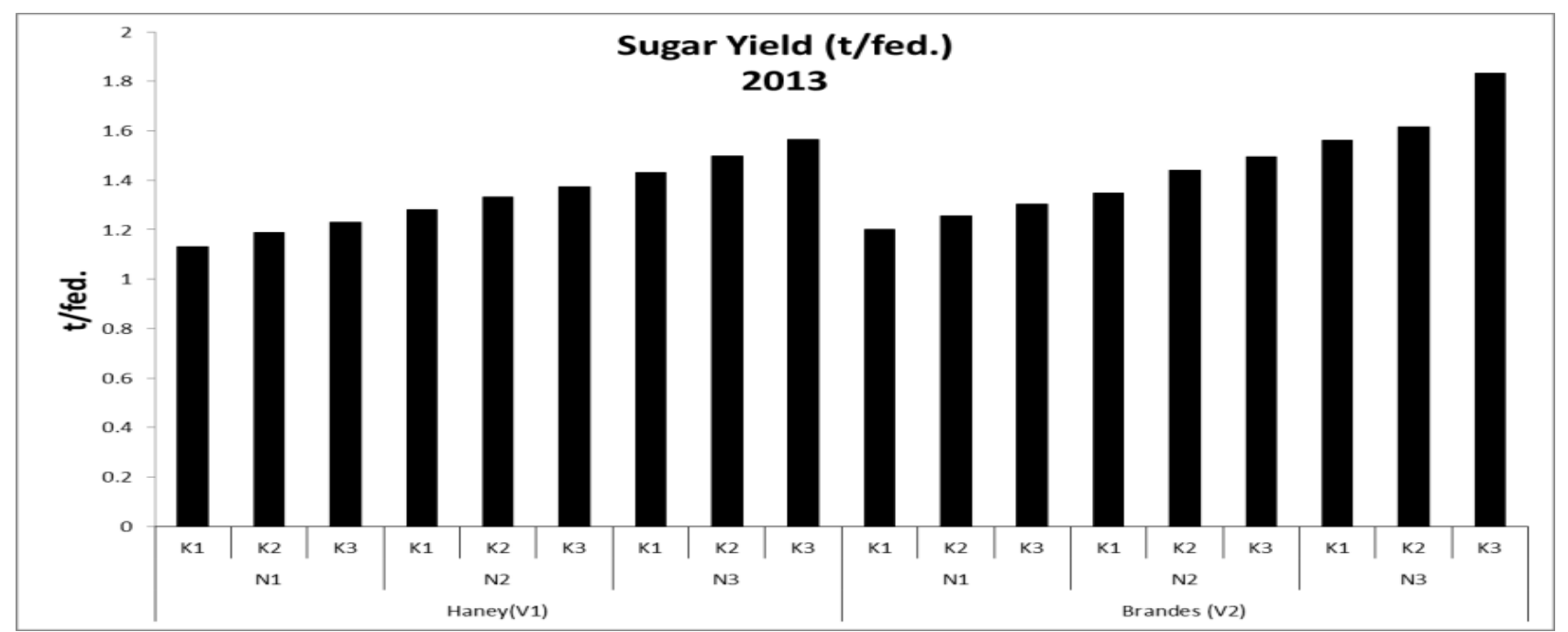

Due to their low relative contributions, the other variables were not included in the model. Consequently, based on the final step of stepwise regression analyses, the equation for prediction of sugar yield $(Y)$ can be obtained:

$$
\begin{aligned}
& Y=-2.9+0.07 X_{5}+0.045 X_{10}+0.07 X_{7} \\
& +0.0001 X_{4}-0.0003 X_{3}-0.008 X_{6}
\end{aligned}
$$

In the $1^{\text {st }}$ season

$$
\begin{aligned}
& Y=-2.7+0.07 X_{5}+0.1 X_{7}+0.03 X_{10}+ \\
& 0.0002 X_{4}-0.05 X_{2}-0.0002 X_{3}
\end{aligned}
$$

In the $2^{\text {nd }}$ season

Best subsets regression assesses all possible models and displays a subset along with their adjusted R-squared and Mallows' Cp values (Table 5). The results of the first model for the stem height, stem diameter, stem weight, stem yield, brix \%, sucrose \%, purity $\%$ and juice extraction $\%$ showed that high adjusted $\mathrm{R}^{2}=99.80$ and $99.90 \%$, low Mallows $\mathrm{Cp}=7.20$ and 6.50 and low standard error $=0.0041$ and 0.0038 in the $1^{\text {st }}$ and $2^{\text {nd }}$ seasons, respectively. However, the second model for the stem height, stem diameter, leaves weight, stem weight, stem yield, brix $\%$, sucrose $\%$, purity $\%$ and juice extraction $\%$ showed that high adjusted $\mathrm{R}^{2}=$ 99.80 and $99.90 \%$, low Mallows $\mathrm{Cp}=9.00$ and 7.60 and low standard error $=0.0042$ and 0.0038 in the $1^{\text {st }}$ and $2^{\text {nd }}$ seasons, respectively.

In conclusion, this study evaluated the effects of nitrogen and potassium fertilization levels on yield and quality of two sweet sorghum varieties Honey and Brandes. Two years of study indicated that the highest yield of sugar and juice and quality were obtained by Brandes variety with higher level of nitrogen $120 \mathrm{~kg} \mathrm{~N} / \mathrm{fed}$ and potassium $75 \mathrm{~kg} \mathrm{~K} / \mathrm{fed}$.

\section{References}

A.O.A.C. 1995. Official Methods of Analysis Published by the A.O.A.C. Box 540, Washington.

Abd El-Razek, A.M. and S.Y. Besheit 2009. Potential of some sweet sorghum 
Sorghum bicolor L. Moench) varieties for syrup and ethanol production in Egypt. Sugar Tech., 11(3): 239-245.

Adeli, A. and J.J. Varco. 2002. Potassium management effects on cotton yield, nutrition and soil potassium level. $J$. Plant Nutr., 25: 2229-2242.

Almodares, A. and M. Goli. 2013. Preliminary study on the effect of plant population density and sweet sorghum cultivars on bioethanol production, Biofuels., 4: 2, 163-167.

Almodares, A. and M.R. Hadi 2009. Production of bioethanol from sweet sorghum: a review. Afr. J. Agric. Res., 4: 772-780.

Almodares, A. and S.H. Hoseini. 2016. Effect of sowing dates and nitrogen levels for ethanol production from sweet sorghum stalks and grains. Afr. J. Agric. Res., 11(4): 266-275.

Almodares, A., R. Taheri1, III. M. Chung and M. Fathi. 2008. The effect of nitrogen and potassium fertilizers on growth parameters and carbohydrate contents of sweet sorghum cultivars. $J$. Environ. Biol., 29(6): 849-852.711716.

Aly, M.H., Amal M. Kamel and Samia Hassan. 2008. The usage of biofertilizer to minimize the mineral fertilizer for sweet sorghum. Egypt. J. Appl. Sci., 23 2(B): 486-499.

Antonopoulou, G., H.N. Gavala, I.V. Skiadas, K. Angelopoulos and G. Lyberatos 2008. Biofuels generation from sweet sorghum: fermentative hydrogen production and anaerobic digestion of the remaining biomass. Bioresour. Technol., 99, 110-119.

Benlhabib, O., A. Yazar, M., E. Qadir, Louren'o and S.E. Jacobsen 2014. How can we improve Mediterranean cropping systems. J. Agronomy and Crop Sci., 200: 325-332.

Draper, N.R. and H. Smith. 1981. Applied regression analysis. $2^{\text {nd }}$ edition, Wiley series in probability and mathematical statistics, John Wiley \& Sons. N.Y., pp. 709.

EL-Sheikh, S.R.E., A.H.S.A. EL-Labbody and A.M.H. Osman 2011.Response of three sweet sorghum varieties to potassium mineral -and bio fertilization. Egypt. J. Agric. Res., 89(3):1019- 1027.

Gomez, K.A. and Gomez, A.A. 1984. Statistical Procedures For Agricultural Research. Book John Willey and Sons Inc., New York.

Howell, T.A., J.L. Steiner, A.D. Schneider; S.R. Evett and J.A. Tolk 1997. Seasonal and maximum daily evapotranspiration of irrigated wheat, sorghum, and corn-Southern High Plains. Transactions of the ASAE, 40(3):623-634.

Lipinski, E.S. 1978. Sugar crops as a source of fuels, vol. II. Processing and Conversion, Research Dept. of Energy. Final Report. Battelle Columbus Labs, $\mathrm{OH}$.

Martin, J.H., W.H. Leonard and D.L. Stamp 1990. Principles of field crop production. Third ed. Macmillan Publishing Co., Inc. New York.

Mekdad, A.A.A. 2015. Sugar beet productivity as affected by nitrogen Fertilizer and foliar spraying with boron. Int. J. Curr. Microbiol. Appl. Sci., 4(4): 181-196.

Mekdad, A.A.A. and M.M. Rady 2016. Response of Beta vulgaris L. to nitrogen and micronutrients in dry environment. Plant Soil Environ., 62(1): 23-29.

Mengel, K. and E.A. Kirkby 2001.Principles of plant nutrition. $5^{\text {th }} \mathrm{Ed}$, Kluwer Academic Publisher., pp. 605-650.

Mohamed, K.E., H. Ferweez and S.M. Allam. 2006. Effect of $\mathrm{K}$ fertilization on yield and quality of sweet sorghum 
juice and syrup. Bull. Fac. Agric. Cairo Univ., 57: 401-416.

Nitoses, R.E., and Evans, H.G. 1969.Effect of univalent cations on the activity of particulate starch synthase. Plant Physiol., 44: 1260-1266.

Pholsen, S. and N. Sornsungnoen. 2004. Effects of nitrogen and potassium rates and planting distances on growth, yield and fodder quality of forage sorghum Sorghum bicolor L. Moench. Pakistan J. Bio. Sci., 7, 1793-1800.

Reddy P.S., B.V.S Reddy, A. A. Kumar and P.S. Rao 2008. Standardization of nitrogen fertilizer rate for sugar yield optimization in sweet sorghum. J. SAT Agri. Res., 6: 1-4.

Rego, T.J., V.R. Nagesvara, B. Seeling, G. Pardhasaradhi and D.K. Kumar. 2003. Nutrient balance a guide to improving sorghum and ground based dry land cropping systems in semi-arid tropical India. Field Crops Res., 81: 53-68.

Rutto, L.K., Y. Xu, M. Brandt, S. Ren, M. K. Kering. 2013. Juice, ethanol, and grain yield potential of five sweet sorghum Sorghum bicolor [L.]Moench) cultivars. J. Sustainable Bioenergy Systems, 3, 113-118.

Singh, D., S. K. Saini and S. K. Sinha. 2008. Performance of sugarcane genotypes under different fertility levels. In:
Proceedings of the National Seminar on varietal planning for improving productivity and sugar recovery in Sugarcane held at G.B.P.U.A. \& T. Pantnagar, 14-15 February 2008, 240241.

Soil Survey Staff. 1999. Soil taxonomy. A basis system of soil classification for making and interpreting soil surveys. Second Edition, Agriculture Handbook No. 436. Washington DC): USDA.

Tsialtas, J.T. and N. Maslaris 2005. Effect of $\mathrm{N}$ fertilization rate on sugar yield and non-sugar impurities of sugar beets Beta vulgaris) grown under Mediterranean conditions. J. Agron. Crop Sci., 191, 330-339.

Uchino, H., T. Watanabe, K. Ramu, K.L. Sahrawat, S. Marimuthu, S.P. Wani and O. Ito. 2013. Effects of Nitrogen Application on Sweet Sorghum Sorghum bicolor L.)Moench) in the Semi-Arid Tropical Zone of India. J.A.R.Q., 47(1): 65 - 73 .

Usofzadeh, M., M. Daneshvar, A. Almodares and H.R. Eisvand. 2013. Effects of nitrogen fertilizer and plant growth regulator on stalk yield and bioethanol in sweet sorghum. Iranian J. Plant Physiol., 3(3): 711-716.

\section{How to cite this article:}

Mekdad, A.A.A., and El-Sherif, A.M.A. 2016. The Effect of Nitrogen and Potassium Fertilizers on Yield and Quality of Sweet Sorghum Varieties under Arid Regions Conditions. Int.J.Curr.Microbiol.App.Sci. 5(11): 811-823. doi: http://dx.doi.org/10.20546/ijcmas.2016.511.092 